\title{
Anti-fungal capacity of Saga leaf (Abrus precatorius l) towards Candida albicans testing
}

\author{
Muslim Paranto NA, Karlina Harjadinata, Warta Dewi \\ Department of Dental Material Science \& Technology Faculty of Dentistry Universitas Padjadjaran
}

\begin{abstract}
The aim of this study was to evaluate the antifungal effect, by determining the Minimum Inhibitory Concentration (MIC) of saga leave extract againts Candida albicans, as a causal of oral candidiasis. The saga leave were extracted following masseration method. Candida albicans, as a tested fungal was isolated from patients at the Oral and Dental Hospital Faculty of Dentistry Universitas Padjadjaran. They were cultured on Sabouraud Agar plate, incubated at $37^{\circ} \mathrm{C}$ for $18-24$ hours. The isolation and the identification of Candida albicans were based on colonial morphology and the fermentation of glucose, maltose, succharose, dan lactose at the Microbiology Laboratory. This experimental laboratory study was conducted according to a serial dilution method from $16 \mathrm{mg} / \mathrm{ml}$ up to $0,25 \mathrm{mg} / \mathrm{ml}$ of saga leave extract with two-fold dilution in three repetitions. The result showed that the Saga leave extract be able to inhibit Candida albicans at minimum $2 \mathrm{mg} / \mathrm{ml}$ concentration. As a conclusion, the concentration of 2 $\mathrm{mg} / \mathrm{ml}$ or more of saga leave extract has antifungal effect againts Candida albicans.
\end{abstract}

Key words: Saga leave extract, Candida albicans, antifungal effect

\section{INTRODUCTION}

Oral infection may be caused by various microorganisms including bacteria, virus and fungus. One of the fungus that is frequently found in the oral cavity is Candida albican. ${ }^{1}$ Candida can be found on normal mucous membrane such as oral mucosa, vaginal mucosa and digestive tract mucosa. Candida albicans that is commensal is sometime found in the healthy human digestive tract. ${ }^{2}$ In certain conditions, such as in cell immunity disturbance, such as in AIDS patients or the lost oral normal flora due to broad spectrum antibiotic therapy, Candida may become invasive and occurs in the form of various acute and chronic infection or localized lesion. This is caused by the lack of nutrition competition with other organisms that Candida can grow rapidly. Therefore, basically, the infection is very much influenced by the host condition, not only by the virulence of the fungus.

Candida albicans infection can be treated by oral nystatin. ${ }^{3}$ For the digestive tract disease due to Candida, intravenous amphotericin $B$ is used. ${ }^{4}$ Besides, it can also be treated topically using clotrimazole and orally using ketoconazole. ${ }^{3}$ The use of those drugs may have side effects including nausea, burning sensation, erythema, and disturbing edema. Another side effects that sometimes occur are headache, epigastric pain, photophobia, paresthesia, and gum bleeding. ${ }^{5}$

The prevalence of candidiasis is still high in 
Indonesia with an average of $41.66 \% .^{6}$ Currently, the treatment given generally uses synthetic medicine. However, those drugs often trigger side effect which is a disadvantage for the patients. Synthetic drugs are also toxic for human who needs to neutralize the toxic nature in the heart. Another problem is the price of the synthetic drugs. The expensive treatment and the existing social economic condition of the population, especially the lower class population makes treatment and cure difficult. In relation with the above condition, other alternative treatments are started to be sought.

Herbal medicine that uses herbs as the main materials is now starting to be developed. In addition to the fact that the price is more affordable, the side effect of this herbal medicine is mild. People can grow the herbs in the area surrounding the house so that they can use it anytime. The term that is often used for the grown herbs in the house is TOGA (Tanaman Obat Keluarga) or family herbal plants.

One of the herbs that are potential to grow is saga (Abrus precatorius), a wild bush that is frequently seen in rural areas. The parts that are often used for herbal medicine is the leaves and seeds. ${ }^{7}$ The leaves are often used as antibiotics. ${ }^{8}$ It can also be used as flu and dysentery. ${ }^{9}$ In addition, saga leaf can also be used to reduce mouth ulcers.

The various functions of Saga (Abrus precatorius) in medicine are due to the element in the plant. The sweet saga leaf is originally thought as containing of glychirrhizine only but further study reveals that it also contains glycoside including anti bacterial Abrucyde A$D$ and Abrusgenin and a small amount of toxic abrin. ${ }^{10}$ The seed contains alkaloid compound including abrin, choline, trigoline. ${ }^{8}$

The studies performed ${ }^{11}$, show that saga leaf extract can inhibit the growth of Pasteurella multosida and Corynebacterium sp. Saga seed extract has the ability to inhibit the growth of Moraxella sp. Prajogo and Dyatmiko ${ }^{12}$, have performed a study using saga leaf extract using three types of solvents, i.e. methanol, ether, and butanol showing that the three solution is able to prevent Candida albicans growth through contact for 16 hours. From the results of this study, it has been proven that butanol fractioned saga extract has the best inhibitory power.

The aim of this study is to describe the presence antifungal property and determine Minimum Inhibitory Concentration (MIC) of saga leaf extract towards Candida albicans to establish saga leaf extract as the alternative medicine for oral and dental diseases, particularly those caused by Candida albicans because different locations of the disease can lead to different results.

\section{METHODS}

The study performed is laboratory experiment to determine the antifungal ability of saga leaf extract (Abrus precatorius) through Minimum Inhibitory Concentration (MIC) towards Candida albicans based on the sensitivity test using serial dilution method. The study is performed in the period of July 2006 to February 2007 at the Microbiology Laboratory of Faculty of Dentistry Universitas Padjadjaran. The population is the saga plants grown in Bandung district with extracted wet saga leaf grown in Ciwidey area.

The extraction of saga leaf was performed using maceration method. Five hundred and fourteen grams of saga leaf powder was added to 2.5 litres of $95 \%$ methanol solvent and let still for 5 days with regular mixing every 24 hours. After 5 days, the mixture was filtered and the sediment was separated. The sediment was then placed in a tube to be re-extracted by flowing methanol from the upper part of the tube to dilute the residual active agents. This treatment was repeated three times so that the compound of the saga leaf can be extracted optimally.

The filtered extract was then treated by rotavapor producing dry extract. The methanol fractionated dry extract was then suspended with water and re-extracted using ether. The ether fraction was dried and the re-extracted using $70 \%$ butanol. The extract fraction was then treated with rotavapor to produce dry extract to be used as test material.

The test fungus was isolated Candida albicans from oral mucosa swab. The culture media used for sensitivity test was Saboraud Glucose Agar.

To get test fungus, one oese of oral mucosa swab. The swab was inserted to a tube containing bullion to be cultured in SGA and for further microbiology tests. 
Table 1. Serial dibullion of Saga leaf exract solution.

\begin{tabular}{cccccc}
\hline $\begin{array}{c}\text { Tube } \\
\text { Number }\end{array}$ & $\begin{array}{c}\text { Bullion } \\
(\mathrm{ml})\end{array}$ & $\begin{array}{c}\text { Saga leaf } \\
\text { extract (SLE) }\end{array}$ & $\begin{array}{c}\text { SLE dilution } \\
(\mathbf{x})\end{array}$ & $\begin{array}{c}\text { SLE final } \\
\text { concentration }(\mathrm{mg} / \mathrm{ml})\end{array}$ & $\begin{array}{c}\text { Candida suspension } \\
(\text { Mc Fahrland 0.5) }(\mathrm{ml})\end{array}$ \\
\hline 1 & - & $4 \mathrm{ml}$ & 1 & 16 & 0.1 \\
2 & 2 & $2 \mathrm{ml}$ of tube 1 & 2 & 8 & 0.1 \\
3 & 2 & $2 \mathrm{ml}$ of tube 2 & 4 & 4 & 0.1 \\
4 & 2 & $2 \mathrm{ml}$ of tube 3 & 8 & 2 & 0.1 \\
5 & 2 & $2 \mathrm{ml}$ of tube 4 & 16 & 1 & 0.1 \\
6 & 2 & $2 \mathrm{ml}$ of tube 5 & 32 & 0.5 & 0.1 \\
7 & 2 & $2 \mathrm{ml}$ of tube 6 & 64 & 0.25 & 0.1 \\
8 & - & $2 \mathrm{ml}$ of tube 7 & - & $\mathrm{KN}$ & - \\
9 & 2 & $2 \mathrm{ml}$ of tube 8 & - & $\mathrm{KP}$ & 0.1 \\
\hline
\end{tabular}

For microscopic test material (MTM) a direct preparation on object glass was made from the oral mucosa swab. After the preparation was fixated and dyed using Gram dye, it was observed under the microscope. In addition, one oese test material was cultured in SGA using lining method and then incubated for 18-24 hours in a temperature of $37^{\circ} \mathrm{C}$.

On the next day, the suspected colonies of Candida albicans on SGA were isolated and identified microscopically through Gram dye and biochemical tests based on fermentation test on carbohydrate: glucose, maltose, saccharose, and lactosa. As the pH indicator, red phenol was added. After the gas was formed, Durham tube is placed in an inversed position.

The determination of minimum inhibitory concentration is performed based on serial dilution method in reaction tube. The saga leaf extract was weigh, $80 \mathrm{mg}$, placed into $5 \mathrm{ml}$ sterile bullion to get standard solution with a concentration of 16 $\mathrm{mg} / \mathrm{ml}$. Using pipettes, $4 \mathrm{ml}$ of standard solution is placed into the tube. Reaction tube number 27 and 9 is filled with $2 \mathrm{ml}$ of sterile bullion. In tube $2,2 \mathrm{ml}$ of the solution of tube 1 was added and then mixed until homogenous and a solution with $2 \times$ dilution of $8 \mathrm{mg} / \mathrm{ml}$. Furthermore, $2 \mathrm{ml}$ of mixture from tube 2 was removed to tube 3 , mixed to homogenous until $4 \mathrm{x}$ dilution was gained or a concentration of $4 \mathrm{mg} / \mathrm{ml}$. This dilution technique was applied to the next tubes to reach a concentration of $2 ; 1 ; 0,5 ; 0,25 \mathrm{mg} / \mathrm{ml}$ in tube 4 , 5,6 , and 7 . The residual $2 \mathrm{ml}$ of tube 7 is inserted to empty tube 8 as negative control.

The Candida albicans suspension was made with a turbidity that matched Mc Fahrland 0.5 standard and was placed into tube 1-7, each 0.1 $\mathrm{ml} .0 .1 \mathrm{ml}$ of the suspension was removed using pipettes to tube 9 that only contained sterile bullion as positive control.

All cultures in the tube were incubated in a temperature of $37^{\circ} \mathrm{C}$ for $18-24$ hours. The next day, the cultures in the tube were observed for its turbidity. The tube that showed clear culture showed that the test material was able to inhibit the growth of the microorganism. On the contrary, the turbid solution showed that the test microorganism grew because the test material was unable to inhibit it. The Minimum Inhibitory Concentration is the minimum concentration of the test material that is able to inhibit the microorganism growth in the tube.

To assure that the microorganism growth in each tube was actually presence, one oese was taken and growth in sectors on SGA plate. The SGA was then incubated aerobically in a temperature of $37^{\circ} \mathrm{C}$ for $18-24$ hours. The area that did not have Candida albicans showed the saga leaf extract concentration that has antifungal property. The smallest extract concentration that shows the lowest Candida albicans growth is the Minimum Inhibitory Concentration of Saga leaf extract.

\section{RESULTS}

\section{Saga leaf extraction result}

The extraction of saga leaf was performed using maceration method with $95 \%$ methanol solvent that produces thick solution that, if it is left still, will produce sediment with water on it. To 
remove the water produced during the procedure, the extract was treated using rotavapor. After the extraction using ether solvent was performed, drier extract was gained with dark green color. From 514 grams of dry saga leaf, 40 grams of saga leaf extract was gained.

The saga extract test with ether fraction towards Candida albicans does not show good result because Candida albicans can still grow in the concentration of $16 \mathrm{mg} / \mathrm{ml}$. On the contrary, saga extract can be re-extracted using $70 \%$ butanol solvent that produces good inhibitory property towards Candida albicans.

\section{Fungus isolation and identification result}

The microscopic examination towards MTM collected from oral mucosa swab using Gram dye shows that the fungus colony is oval, Gram positive with a size that is bigger than the bacterial size. Although fungal colonies are more dominant, the colonies are still mixed with other bacterial colonies, especially Gram Positive Rod bacteria.

The Sabouraud's Glucose Agar (SGA) cultures from the MTM and which are incubated in a temperature of $37^{\circ} \mathrm{C}$ for $18-24$ hours show a colony growth with yellowish white characteristic, yeast like odor, smooth and slippery colony surface that is suspected that the colonies are Candida albicans colonies. On SGA, there are also other bacterial colonies with a characteristic that is similar to Candida but produces phlegm.

Themicroscopic examination results from the SGA cultures show an oval fungal image with a size bigger than bacterial size, purpleand Gram positive. The fermentation test for colonies suspected as Candida albicans towards carbohydrates show a fermentation reaction for glucose, maltose and sucrose. The reactions are marked by the change in the color of the red phenol indicator to yellow. In the tube containing glucose and maltose, gas as a result of the fermentation is produced as an addition of change in indicator color. In sucrose, no gas is formed. Fermentation with lactose does not show any reaction, the color is still red and no gas is formed.

Based on the identification, both from the morphological examination of the colonies, microscopic examination and fermentation test, the colonies grown on SGA can be diagnosed as Candida albicans.
Minimum inhibitory concentration of saga leaf extract towards candida albicans

Sensitivity test of Candida albicans towards saga leaf based on serial dilution method shows that the cultures in tube 1-3 are clear, only dark green sediment from saga leaf extract is seen. Cultures in tubes number 4-7 are changed into a turbid culture, almost as turbid as the positive control tubes. From all repetation, the negative control tube is still clear and positive control is always turbid.

The changes in cultures in the tube to a turbid solution show that fungus have grown. On the contrary, the clear culture shows lack of growth. From this visual observation, it can be estimated that the minimum concentration that can inhibit Candida albicans is in tube 4. The result of the observation can be observed in the below table.

The result of sectored cultures on SGA shows that there is no growth in sector $1(16 \mathrm{mg} / \mathrm{ml})$; $2(8 \mathrm{mg} / \mathrm{ml}) ; 3(4 \mathrm{mg} / \mathrm{ml})$, and negative control. This shows the presence of saga extract inhibitory property towards Candida albicans growth. In sector 4, which is collected from culture in tube 4 with a saga extract concentration of $2 \mathrm{mg} / \mathrm{ml}$, shows fewer Candida growth compared to fungal growth in sectors 5-7. This shows that the minimum concentration that can inhibit Candida albicans is $2 \mathrm{mg} / \mathrm{ml}$.

\section{DISCUSSION}

From the performed extraction, it turns out that saga leaf contains a lot of water. From $14 \mathrm{~kg}$ of wet saga leaf, only 514 grams dry saga leaf is collected. This shows a high water content of saga leaf, more or less $95 \%$. From the overall weight of dry saga leaf 40 grams of saga leaf extract is collected. This amount shows that the active content of saga leaf is $7.8 \%$ of its dry weight.

The change in red phenol indicator into yellow is caused by decreased solution $\mathrm{pH}$. Basically, fermentation is a process of carbohydrate molecule break down, which in this study glucose, maltose, sucrose and lactose are used, that creates acid and sometimes followed by hydrogen or carbon dioxide gas as the side product of the fermentation. The gas formed will be seen as air bubble in the tube. The effect of acid production 
Table 2. Results of the determination of minimum inhibitory concentration towards Candida albicans in Tubes.

\begin{tabular}{cccccccccccc}
\hline \multirow{2}{*}{ Sample } & Repeat & \multicolumn{10}{c}{ SLE concentration $(\mathrm{mg} / \mathrm{ml})$} \\
\cline { 2 - 10 } & & 16 & 9 & 4 & 2 & 1 & 0.5 & 0.25 & $\mathrm{KN}$ & $\mathrm{KP}$ \\
\hline \multirow{2}{*}{1} & 1 & - & - & - & \pm & + & ++ & ++ & - & ++ \\
& 2 & - & - & - & \pm & + & ++ & ++ & - & ++ \\
2 & 1 & - & - & - & \pm & + & ++ & ++ & - & ++ \\
& 2 & - & - & - & \pm & + & ++ & ++ & - & ++ \\
3 & 1 & - & - & - & \pm & + & ++ & ++ & - & ++ \\
\hline & 2 & - & - & - & \pm & + & ++ & ++ & - & ++ \\
\hline
\end{tabular}

during fermentation process is lower $\mathrm{pH}$. As the indicator of $\mathrm{pH}$ change, the red phenol will turn to yellow. On the contrary, if there is no fermentation reaction, the indicator will stay red. ${ }^{13}$

When determining minimum inhibitory concentration visually, from all repeats, the negative control tube stays clear because it only contains saga extract suspension in bullion, without Candida albicans suspension. This shows that saga extract used as test material does not contain bacteria. In positive control tube, only Candida albicans solution in bullion is found, without saga leaf extract leading to turbid appearance in every repeat. This means that the test microorganism is able to grow in the media used.

The sectored culture in SGAshows a minimum concentration of saga extract in solution that has an inhibitory property towards Candida albicans as $2 \mathrm{mg} / \mathrm{ml}$. The inhibitory property owned by saga is caused by the presence of glycirrhizine, glycocide compound that makes saga leaf sweet. In addition, saga leaf also contains flavanoid compound and lypolytic enzyme. Those compounds have anti bacterial activity.

On average, saga leaf contains 15\% glychirrhizine of all active contents in saga leaf. ${ }^{14}$ During extraction, glychirrhizine can be hydrolized into sugar compound. Strong interaction between sugar molecule and water molecule in solution leaves a small amount of water to support microorganism life. Sugar level in saga will make the environment surrounding bacteria becomes hypertonic. The high osmotic pressure will cause liquid movement from bacterial cell to the environment leading to bacterial cell shrinkage (plasmoptysis) and microorganism cell death. ${ }^{15}$

The flavanoid compound in saga leaf, such as abrectorin, also influences the inhibitory property towards Candida. In general, flavanoid compound is a lypophylic compound. The more lypophilic the flavanoid the more destruction it brings to the cell membrane leading to cell component lysis that in turns will cause cell death. Flavonoid binds with cell wall lipid layer and destroy lipid structure that will disturb metabolism, nutrient transport, and increase cell wall permeability. ${ }^{16}$

Other agent found in saga leaf is lypolytic enzyme ${ }^{14}$, that also plays a role in inhibitory property of saga leaf despite the relatively small amount of this enzyme is seen in the leaf. The mechanism of this enzyme is not too different from the flavanoid compound, i.e. destructing lipid layer leading to disturbance in fungal metabolism and nutrient transport.

From this study, it is proven that saga leaf has inhibitory property towards Candida albicans. This implies that saga leaf can be developed as an alternative medicine in therapy of Candida albicans infection.

Until recently, saga leaf has been used by the people to cure various diseases. In addition to the antifungal property, glychirrhizine found in the leaf can also work as expectorant. ${ }^{17}$ This is the reason why saga leaf is often used as coughing cure.

The use of saga leaf as a medicine does not make it necessary to use it in the extract form. It can be use in a simpler form such as in the form of traditional mouthwash. Dry saga leaf can be ground and then mixed with warm water and used as mouthwash. It can also be chewed to heal mouth ulcer or stomatitis caused by Candida albicans. Further research is very important because this leaf has many beneficial use that it can be used as alternative medicine in the medical world. 


\section{CONCLUSION}

Based on the study results using serial dilution, it can be concluded that the Minimum Inhibitory Concentration (MIC) of saga leaf extract (Abrus precatorius $L$ ) towards Candida albicans is $2 \mathrm{mg} / \mathrm{ml}$. To inhibit Candida albicans, it is better to use a saga leaf extract concentration of $2 \mathrm{mg} /$ $\mathrm{ml}$ or more.

\section{REFERENCES}

1. David B. Bacteriology and immunology for students of medicine. London: William Clawes; 1989.

2. Schmid J. Molecular microbiology of candida albicans. Massey University; 2003.

3. Eversole LR. Oral medicine. A pocket guide. Philadelphia: W.B. Saunders Co.; 1996.

4. Bhattacharyya I, Cohen DM, Sol S. Red and white lesions of the oral mucosa. In: Burket's oral medicine diagnosis \& treatment. $10^{\text {th }}$ ed. Ontario: BC Decker Inc.; 2003.

5. Ganiswarna SG. Farmakologi dan terapi. Jakarta: Gaya Baru; 1995.

6. Soenartyo H, Astuti ER. Pengaruh penurunan kadar Fe dan kebersihan rongga mulut wanita hamil terhadap terjadinya kandidiasis. Maj
Il Kedokt Gigi FKG Usakti 1999; Edisi Khusus FORIL VI.

7. Simpson. Herbal botany. Singapore: Fang \& Song Printers.; 1986.

8. Wistpal E, Jensen PM. Plant resource 07. Prosea; 1989.

9. [cited 2006 Oct] Available from:http://www. bsienvis.org.htm.

10. Dwivedi SK, Sharma MC. Therapeutic evaluation of an indigenus drugs formulation againts Scabies. Indian J Med 1985.

11. Prajogo B, Dyatmiko W. Aktivitas antimikroba daun Abrus precatorius. Warta Tanaman Obat Indonesia 1993.

12. Cappuccino JG, Sherman N. Microbiology: A laboratory manual. $6^{\text {th }}$ ed. New York: Benjamin Cummings; 2001.

13. Sundari $D$, Wien $M$, Pudjiastuti. Informasi penetian khasiat keamanan dan fitokimia tanaman Saga. Warta Tumbuhan Obat Indonesia 1993.

14. Burton G, Engelkirk PG. Microbiology for the health sciences. $5^{\text {th }}$ ed. New York: Lippincott; 1996.

15. Jawetz E, Melnick EA, Adelberg. Mikrobiologi kedokteran. Edisi ke 20. Jakarta: EGC; 1996.

16. Society of Japan Pharma. Japanesse pharmacopeia. $14^{\text {th }}$ ed. Tokyo: Yakuji Nippo, Ltd.; 2001. 